works less well collected by major libraries: prayer books, newsletters, Papal indulgences (perhaps 30 percent of the surviving printed documents from the fifteenth century), the Reformation's warring pamphlets, best-selling vernacular works (especially chivalric romances), and bread-and-butter Latin grammars and other educational works. In all cases, Pettegree is able to back up his narrative with concrete data from a variety of sources, often including counts of specific print runs to demonstrate the relative profitability of a particular printed edition.

The third and fourth sections of The Book in the Renaissance evolve into even more interesting and even more esoteric subjects; in these chapters, the history of print is a lens and data point through which to view several different areas of more general social history. Printed books are examined as a point of political and religious conflict (via incidents of book burnings and mass censorship), as a philosophical grounding point in strifetorn France, as a benchmark for economic distribution in the midst of confessional wars, and as participants in the sixteenthcentury development of technical scientific illustration and medical practice. Finally, he offers a chapter ruminating on the effects of widespread printing on the Renaissance concept of the library itself: the collections that had once been the province (and the pride) of great lords became possible for average scholarship, and the erudite discourse once relegated to the libraries of the nobility were now possible in the stationer's shop.

Pettegree admits, however, that even this more boisterous history of early European printing may still be incomplete. Plantin kept a single copy of everything he printed, no matter how ephemeral; for how many other presses are the complete riches of history lost? Booksellers' inventories can be quite revealing, but if they represent unsold inventory, do we gain a complete picture? Pettegree closes his history with two counterexamples to his own approach. After noting the too- numerous examples of book destruction in the course of warfare (up to World War II and the Gulf wars), he notes an instance in 1989 in which Dutch workmen discovered a group of Protestant books apparently hidden more than four hundred years prior in a house in Delft; fully four of the six books had no other known exemplars anywhere in the world. In a different example, the prolific scrapbooks of the sixteenth-century diarist Pierre de L'Estoile apparently preserve vestiges of a variety of "street" sources, many of them apparently printed broadsheets and newsletters currently lost to our knowledge.

In his conclusion, Pettegree brings to a crux both the potentially paradigm shift of his approach and its inherent limitation. It is certainly true that the history of the book as traditionally written has been centered on the printed books of highest value, the volumes most assiduously sought after and carefully preserved by nobles, scholars, collectors, and (later) librarians. It is completely appropriate to broaden that history to include the gamut of other works that could fill the corners in a printer's schedule and the gaps in his bottom line. Pettegree's The Book in the Renaissance uses a variety of electronic and more traditional sources to do so. Even so, as with any historical narrative, the author must admit that there are parts of this history that still await excavation.Timothy J. Dickey, Independent Scholar, Columbus, Ohio.

\section{Envisioning Future Academic Library Services: Initiatives, Ideas and Chal-} lenges. Ed. Sue McKnight. London: Facet Publishing, 2010. 247p. (ISBN 9781856046916). LC2010-478131.

Library shelves and book catalogues are filled with volumes prophesying the end of the library world as we know it, with change so imminent and so pervasive that it hardly seems possible for any paperbased book to reach readers before it becomes obsolete. While the coming of, and need for, change is certainly trumpeted in 
this book, this wisely edited collection of diverse and strong essays should have a long shelf life nonetheless.

The essays, written by distinguished librarians, publishers, and professors mostly from the United Kingdom and the Commonwealth, with others from the United States and other international sites, are uniformly succinct, well written, and particularly well edited. Sue McKnight, Professor of Knowledge and Learning Management and Director of Libraries and Learning Management at Nottingham Trent University, deserves praise for the diversity of the essays, their hierarchical arrangement within the volume, and her care in overseeing each contributor's text to make sure there are no tedious redundancies from one to another, and that they interlock and mesh like gears, driving the discussion forward. Edited volumes often suffer from jerky stops and starts in their progress. This volume's acceleration and thrust, gathering speed as it goes, is virtually flawless.

A listing of the essays will suggest the range of the book and its appeal to educators, students in Library and Information Management/Science programs, and those working in academic libraries, whether at the reference desk, in information technology, or occupying directors' offices, planning strategically for today and for times to come.

Sue McKnight sets up the issues facing academic libraries in her opening essay, and the discussion begins with Derek Law reminding us what troubles await if we ignore and fear and minimize the "digital barbarians" at our gates. Penny Carnaby then takes up the "delete generation" and presents case studies from New Zealand to illustrate her topic of how citizen-generated content is transforming libraries. Andrew McDonald takes a refreshing step back from the virtual world to discuss three-dimensional libraries, planning, and layout, but then the virtual world is front and center for the majority of the remainder of the volume. The impact of Web 2.0 on libraries is the topic taken up by James
G. Neal and Damon E. Jaggars, proving a natural segue for P. Charles Livermore's discussion of Second Life (SL), "arguably the most popular and well known... of multi-user-virtual environments." Like many other essayists, he defines his topic, presents pro and con arguments for use of SL in libraries, presents a case study, ruminates on the implications for library staff and library users, and provides references and notes, many beginning with "www." In another natural transition from SL's digital environment, Frances Pinter highlights the manner in which scholarly publishers have had to adapt to this new world. How others-scholars, students, and researchers-also adapt to the digital world, their experiences with search engines and reference staff, and the use and development of "Library 2.0" is the subject of Paul Coyne's chapter. Coauthors Helen Hayes and Philip G. Kent, using the example of the University of Melbourne, discuss knowledge management in university libraries, noting how academic libraries can fully partner in impacting not just their users, but their institutions, communities, and countries. One aspect of that on a national or global scale is the management and sharing by libraries of scientific, technological and medical data, the focus provided by Martin Lewis. Liz Wright opens up the discussion in a new direction, not just predicting the major forces driving change in the next 5 to 10 years, but also predicting the 15 aspects necessary in leaders and leadership in the coming years. Editor Sue McKnight's next contribution argues for leadership among all staff members in adding value to learning and teaching, while referencing Yale's Sterling Memorial Library's pilot program of pairing students with a "personal librarian." The final chapter by Michael Robinson takes a sobering look at the future of academic libraries in China, a thought-provoking essay on the difference and similarities of eastern and western libraries, which, with apologies to Rudyard Kipling, are not destined to remain distinct. 
The essays are much more subtle than this simple listing implies; but the "menu" does suggest the wealth of matter contained in the slender, easy to read, and handily indexed volume. More of a call to arms than a battle plan, the book nevertheless does give concrete examples and suggestions that will be helpful to a variety of readers. The reports of what other institutions are doing across the globe offer not just benchmarks against which to measure our institutions, but examples we may want to research and duplicate. The volume promises much and delivers impressively. - Harlan Greene, College of Charleston.

The History of the Book in the West: A Library of Critical Essays. Farnham, U.K. \& Burlington, Vt.: Ashgate Publishing Ltd., 2010. Vol. I: 400AD-1455, eds. Jane Roberts and Pamela Robertson, xxxii + 515p. \$275.00 (ISBN 9780754627739); Vol. II: 1455-1700, ed. Ian Gadd, xlii + 526p. \$275.00 (ISBN 9780754627715). LC2009-921962.

On May 4, 1515, Pope Leo X issued a peculiar and remarkable decree, the Super impressione librorum (On the printing of books). In it, the Pope acknowledges a deep-seated sociocultural anxiety about the new technology of printing, stating that, although the reading of books can be a profitable pursuit for those seeking knowledge and the invention of printing has helped spread truth and learning more widely and inexpensively than ever before, the very same technology that enables the dissemination of truth also facilitates the transmission and perpetuation of pernicious error that corrupts rather than edifies the reader. Despite any benefits it might offer, in the Pope's opinion - which for all intents and purposes was supposed to reflect the official, ideal view for the entirety of the Christian West-the technology of printing was a new force that, in spite of its many benefits, needed to be assiduously monitored and controlled.

Pope Leo's decree stands at a decisive moment in the history of the book. On the one hand, this declaration invokes a medieval past in which books and the knowledge they contained were created slowly by hand and disseminated among a smaller, more restricted body of readers. Although literacy rates and the spread of reading increased steadily throughout the Middle Ages, accelerating more and more up to the years immediately prior to the invention of printing, the medieval reading public was still comparatively small and both the prescription and proscription of manuscript texts were easier to manage. At the same time, however, the decree also anticipates the explosion in literacy and the spread of reading that would occur throughout the sixteenth and seventeenth centuries in response to major social and religious movements and intellectual developments such as the Protestant Reformation, Renaissance humanism, New World colonization, the development of "modern" science, the emergence of more powerful centralized nation-states, and the growing popularity of Europe's various vernaculars as appropriate and authorized vehicles for printed expression. In the face of a rapidly growing and demanding reading public and the quick spread of the new technology that could feed its ravenous appetite for text, both authorities and readers confronted an unfamiliar environment in which books - and the truth or errors they contained-were more widespread and less controllable than ever before.

The first two volumes of Ashgate's new series, The History of the Book in the West, represent a necessary attempt to define the history of the book, a relatively new scholarly field, at a critical moment in its development. The thirty-five articles included in these volumes embody something akin to a "greatest hits" collection of relevant scholarship produced during the past forty years. Taken together, they provide readers with a firm foundation of authoritative research upon which to build future investigations into the complex history of books, their producers and readers, and their collective cultural 